\title{
THE EFFECT OF WATER/CEMENT RATIO ON THE SULFATE CORROSION OF FINE GRAINED CONCRETE
}

\author{
Martin Vyšvařil ${ }^{1}$, Markéta Rovnaníková ${ }^{2}$, Patrik Bayer $^{3}$ \\ ${ }^{1}$ Brno University of Technology, Faculty of Civil Engineering, Institute of Chemistry, Žižkova 17, 60200 Brno, Czech \\ Republic \\ ${ }^{2}$ Brno University of Technology, Faculty of Civil Engineering, Institute of Chemistry, Žižkova 17, 60200 Brno, Czech \\ Republic \\ ${ }^{3}$ Brno University of Technology, Faculty of Civil Engineering, Institute of Chemistry, Žižkova 17, 60200 Brno, Czech \\ Republic
}

\begin{abstract}
Sulfate corrosion is one of the major threats for durability of concrete constructions and it becomes a major destructor in sewage collection systems where concrete sewer pipes are exposed to sulfates from waste water as well as from biogenic activity of bacteria. The second type of corrosion is termed microbiologically induced concrete corrosion (MICC) and during this process the $\mathrm{pH}$ of the surface of concrete sewer pipes is reduced and it may lead to steel depassivation and results in the corrosion of this steel reinforcement. This paper is focused on the sulfate attack on fine grained concrete where the effect of $0.5 \%$ sulfuric acid emulating MICC and also effect of solution simulating sewage water on the concrete samples with three different water/cement ratios $(w / c=0.4,0.45$ and 0.5) have been investigated. After 1, 3 and 6 months of the corrosive treatment the content of sulfate ions and $\mathrm{pH}$ values in several layers of specimens were determined. It was found that the sulfate ions penetrate into concrete to maximum depth of $20 \mathrm{~mm}$ and the pH of the aqueous leaches of particular layers of the samples was reduced to 11.92 at the most. Thus, the conditions for the depassivation of reinforcement were not met.
\end{abstract}

Keywords: concrete, corrosion, sulfates, $p H$, waste water

\section{INTRODUCTION}

Large amount of concrete and cementitious materials are used in the waste water systems where sulfate attack is one of the major threats for durability of these infrastructures. External sulfate attack characterized by ingress of sulfate ions from surrounding medium leads to the extensive degradation of concrete and reinforced concrete pipes, having significant (negative) implications for the life cycle costing. When concrete is in contact with salts containing sulfate, interactions between the solid phase and the sulfate solutions occur and ettringite and gypsum are observed as main reaction products [1-3]. Ettringite is formed from calcium sulfate (gypsum) and $\mathrm{C}_{3} \mathrm{~A}$ via monosulfate $\left(\mathrm{AF}_{\mathrm{m}}\right)$ according to Eq. (1). Gypsum is the primary product of sulfate attack on concrete (forming by reaction of sulfate anion with calcium hydroxide).

$$
\mathrm{C} \overline{\mathrm{S}} \mathrm{H}_{2}+\mathrm{C}_{3} \mathrm{~A}+10 \mathrm{H} \rightarrow \mathrm{C}_{4} \mathrm{ASH}_{12} \stackrel{2 \mathrm{CS}_{2}+16 \mathrm{H}}{\longrightarrow} \mathrm{C}_{6} \mathrm{AS}_{3} \mathrm{H}_{32}
$$$$
\text { gypsum monosulfate ettringite }
$$

Ettringite and gypsum have considerably larger volume than initial compounds, which leads to increased pressure. Thus, the interactions of sulfate ions with the cement matrix result in disruption of the concrete and significant loss of mechanical strength and mass, and it leads to reduction of service life of sewage pipes made from concrete [2-3].
The concrete pipes, walls and others structures can be affected by sulfate directly from waste water (in the bottom part of pipelines) or produced by microbiological activity (on the sewer crown). Although in sewage pipes there are various microorganisms which can generate many kinds of aggressive species which may damage concrete and reduce the material service life, the most frequent biodeterioration is caused by biogenic sulfuric acid corrosion [4-5]. Under anaerobic conditions in the bottom part of the pipelines, the sulfate reducing bacteria, e.g. Desulfovibrio, reduce sulfurcompounds in the waste water to $\mathrm{H}_{2} \mathrm{~S}$. Due to low solubility of $\mathrm{H}_{2} \mathrm{~S}$, turbulence of waste water and decreasing $\mathrm{pH}, \mathrm{H}_{2} \mathrm{~S}$ volatilizes to the sewer atmosphere, where its concentration can be higher than $200 \mathrm{ppm}$ [6]. $\mathrm{H}_{2} \mathrm{~S}$ redissolves in condensate on the sewer crown and diffuses into the surface layer of the concrete. In aerobic atmosphere, a part of $\mathrm{H}_{2} \mathrm{~S}$ is oxidized into biodegradable element sulfur by oxygen - Eq. (2).

$$
2 \mathrm{H}_{2} \mathrm{~S}+\mathrm{O}_{2} \rightarrow 2 \mathrm{~S}+2 \mathrm{H}_{2} \mathrm{O}
$$

In low $\mathrm{pH}$ environment, biodegradable element sulfur is further oxidized into sulfuric acid $\left(\mathrm{H}_{2} \mathrm{SO}_{4}\right)$ by bacteria. At the beginning of this step, the $\mathrm{pH}$ value of concrete surface of the pipelines above the water line is reduced by carbonation or reaction with other acidic gases (e.g. $\mathrm{H}_{2} \mathrm{~S}$ ). Then sulfur-oxidizing bacteria are able to grown on the concrete surface to produce $\mathrm{H}_{2} \mathrm{SO}_{4}$ which further reduces the $\mathrm{pH}$ of concrete. At lower $\mathrm{pH}$, many bacteria such as Acidithiobacillus thiooxidans, Thiobacillus neapolitanus, 
Thiobacillus ferrooxidans can produce vast amount of sulfuric acid and further reduce the surface $\mathrm{pH}[5,7]$. Sulfuric acid penetrates into concrete and it reacts with portlandite and calcium silicate hydrates which are the main components of concrete based on Portland cement. These reactions lead to the precipitation of gypsum [5]. Thus, the exposure to the thiobacilli leads to chemical sulfate attack on concrete resulting in the neutralization of the concrete surface, cracking and scaling of concrete material accelerated by the sewage flow. The rate of loss of concrete material can be 3-6 mm/year [8]. From this aspect, the sulfate attack in the sewage system is very dangerous, especially in the areas of waste water rich in sulfates or $\mathrm{H}_{2} \mathrm{~S}$.

The corrosion of steel reinforcement is probably the most frequent type of degradation of reinforced concrete structures. Reinforcing bars are protected from corrosion by a thin iron oxide layer (thickness about $10 \mathrm{~nm}$ ) which is formed on their surface due to a high alkalinity of the surrounding concrete - steel passivation [9]. Corrosion may start when this layer is destroyed - steel depassivation: (i) either by chloride ion penetration (when the concentration of dissolved chloride at the depth of the reinforcing steel exceeds a critical value) or (ii) by a reduction in the $\mathrm{pH}$ value of pore solution to values below 9.5. Such a reduction in alkalinity is the result of reaction of the $\mathrm{Ca}(\mathrm{OH})_{2}$ in the concrete mass with the atmospheric $\mathrm{CO}_{2}$ (carbonation) or with sulfuric acid (sulfate attack).

In the analyses of properties of concrete attacked by sulfates, various investigators have been concentrated mainly on mechanical properties, especially the volumetric expansion [7, 10, 11], microstructural properties [12-13] or determination of strength [13-16]. This paper is focused on the sulfate attack on fine grained concrete where the effect of $0.5 \%$ sulfuric acid emulating microbiologically induced concrete corrosion and also effect of solution simulating sewage water on the concrete samples with three different water/cement ratios (w/c $=0.4,0.45$ and 0.5 ) have been investigated by the assessment of $\mathrm{pH}$ and the content of sulfates in several layers of specimens.

\section{EXPERIMENT}

Laboratory specimens $(40 \times 40 \times 160 \mathrm{~mm})$ made of finegrained concrete (in the next text only concrete) with a water to cement ratio of $\mathrm{w} / \mathrm{c}=0.4,0.45$ and 0.5 were manufactured. The compounds in the mix, namely CEM I 42.5 R cement according to CSN EN 196-1 ed. 2 [17] from the cement plant Mokrá and 3 fractions of quartz sand according to CSN 721200 [18] with designation PG 1 (< $0.5 \mathrm{~mm})$, PG $2(0.5-1 \mathrm{~mm})$ a PG $3(1-2.5 \mathrm{~mm})$ from Chlum $u$ Doks, were mixed in the weight ratios of $1: 1: 1$ : 1. The chemical composition and physical properties of used Portland cement are given in Table 1.

Table 1: Chemical composition and physical properties of used Portland cement

\begin{tabular}{|l|l|l|}
\hline Material & & $\begin{array}{l}\text { CEM I 42,5 } \\
\text { R }\end{array}$ \\
\hline Chemical & $\mathrm{CaO}$ & 61.48 \\
\hline
\end{tabular}

\begin{tabular}{|l|l|l|}
\hline \multirow{4}{*}{$\begin{array}{l}\text { composition } \\
\text { wt. \%) }\end{array}$} & $\mathrm{SiO}_{2}$ & 21.26 \\
\cline { 2 - 3 } & $\mathrm{Al}_{2} \mathrm{O}_{3}$ & 5.08 \\
\cline { 2 - 3 } & $\mathrm{Fe}_{2} \mathrm{O}_{3}$ & 3.64 \\
\cline { 2 - 3 } & $\mathrm{SO}_{3}$ & 2.42 \\
\cline { 2 - 3 } & $\mathrm{MgO}$ & 0.86 \\
\cline { 2 - 3 } & $\mathrm{Na}_{2} \mathrm{O}$ & 0.12 \\
\cline { 2 - 3 } & $\mathrm{K}_{2} \mathrm{O}$ & 0.91 \\
\cline { 2 - 3 } & $\mathrm{MnO}$ & 0.07 \\
\cline { 2 - 3 } & $\mathrm{TiO}_{2}$ & 0.29 \\
\cline { 2 - 3 } & L.O.I. & 4.17 \\
\hline \multirow{5}{*}{$\begin{array}{l}\text { Physical } \\
\text { properties }\end{array}$} & Specific surface $\left(\mathrm{m}^{2} \mathrm{~kg}^{-1}\right)$ & 360 \\
\cline { 2 - 3 } & Specific gravity $\left(\mathrm{kg} \mathrm{m}^{-3}\right)$ & 3120 \\
\hline
\end{tabular}

All of the manufactured specimens were unmoulded 24 hours after casting under laboratory conditions $(\mathrm{t}=(22 \pm 2)$ ${ }^{\circ}$ C, R.H. = $\left.(55 \pm 5) \%\right)$ and placed into water bath for another 27 days. Afterwards, the specimens were air-dried for 24 hours and then the bulk density $\left(\square_{v}\right)$, flexural strength $\left(R_{f}\right)$ and compressive strength $\left(R_{c}\right)$ of the samples were determined according to CSN EN 196-1 [17] (see Table 2). The pore structures of the samples included determination of total porosity (Pt; Table 2) and pore size distribution (Figure 1) were studied by high pressure mercury intrusion porosimetry using a Micromeritics PoreSizer 9310 porosimeter. The microstructure of samples was observed by scanning electron microscope MIRA3 (TESCAN).

Table 2: Mechanical and physical properties of concrete samples

\begin{tabular}{|l|l|l|l|l|}
\hline $\mathrm{w} / \mathrm{c}$ & $\square_{v}\left(\mathrm{~kg} \mathrm{~m}^{3}\right)$ & $R_{f}(\mathrm{MPa})$ & $R_{c}(\mathrm{MPa})$ & $\mathrm{P}_{\mathrm{t}}(\%)$ \\
\hline 0.4 & 2248 & 8.16 & 69.88 & 11.89 \\
\hline 0.45 & 2239 & 7.15 & 66.38 & 12.69 \\
\hline 0.5 & 2233 & 6.99 & 64.38 & 13.19 \\
\hline
\end{tabular}

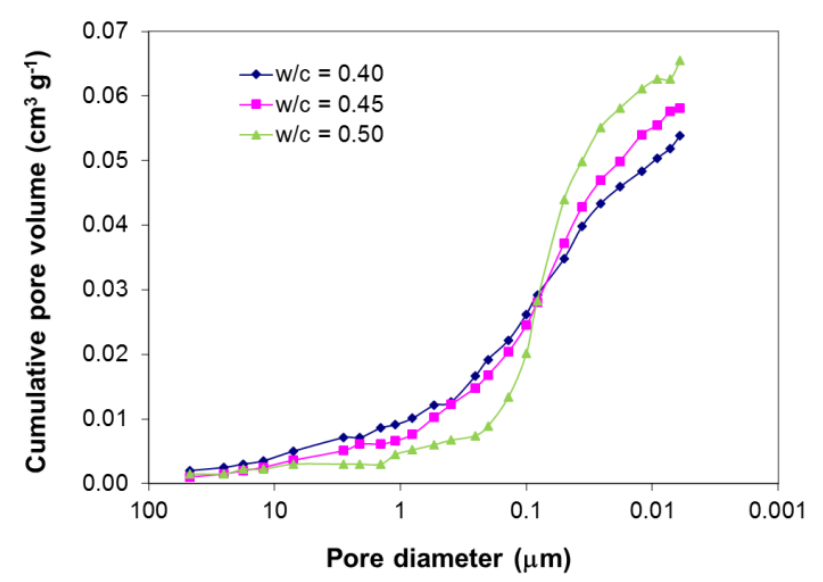

Fig. 1: Pore size distribution of concrete samples

Subsequently, the test samples were graphically segmented on 10 layers of $15 \mathrm{~mm}(\mathrm{I}-\mathrm{X})$ and one layer of $5 \mathrm{~mm}(\mathrm{P})$. The specimens were covered by a protective coat as a drying prevention, and by the whole layer $\mathrm{P}$. They were stand into solution of $0.5 \% \mathrm{H}_{2} \mathrm{SO}_{4}$ or solution simulating waste water (see Figure 2). The concentration of sulfuric acid was chosen in accordance with the literature [19]. Chemical composition of solution simulating waste water is mentioned 
in Table 3. The solution level was maintained at a height of $5 \mathrm{~mm}$ (layer P) and the solutions were weekly renewed. Samples were allowed to soak up for 1 month (all three w/c) and for 3 and 6 months (w/c $=0.4$ and 0.45$)$, then they were cut into characterized layers and dried for 24 hours at $60{ }^{\circ} \mathrm{C}$. After grinding of acquired slices, $\mathrm{pH}$ of their aqueous leaches was determined ( $2 \mathrm{~g}$ sample, $100 \mathrm{ml} \mathrm{H}_{2} \mathrm{O}$ ) and the sulfate content in the layers was measured by $\mathrm{X}$-ray fluorescence spectrometry (expressed as $\mathrm{SO}_{3} \%$ ). The sulfate content in reference concrete sample was $1.11 \%$.

Table 3: Chemical composition of solution simulating waste

\begin{tabular}{|l|l|l|l|l|l|l|}
\hline $\begin{array}{l}\text { compoun } \\
\mathrm{d}\end{array}$ & $\begin{array}{l}\text { casei } \\
\mathrm{n}\end{array}$ & $\begin{array}{l}\text { NaHCO } \\
3\end{array}$ & $\begin{array}{l}\text { ure } \\
\mathrm{a}\end{array}$ & $\begin{array}{l}\mathrm{NaC} \\
1\end{array}$ & $\begin{array}{l}\mathrm{CaCl} \\
2\end{array}$ & $\mathrm{MgSO}$ \\
\hline$c\left(\mathrm{~g} \mathrm{l}^{-1}\right)$ & 1.9 & 5.3 & 4.6 & 1.1 & 0.53 & 0.17 \\
\hline
\end{tabular}

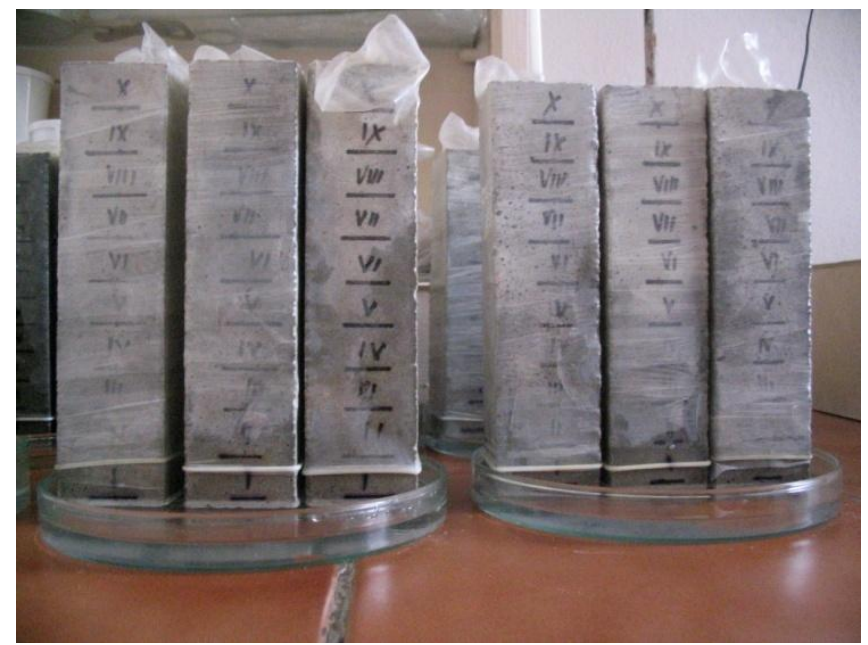

Fig. 2: Concrete samples placed in $0.5 \% \mathrm{H}_{2} \mathrm{SO}_{4}$
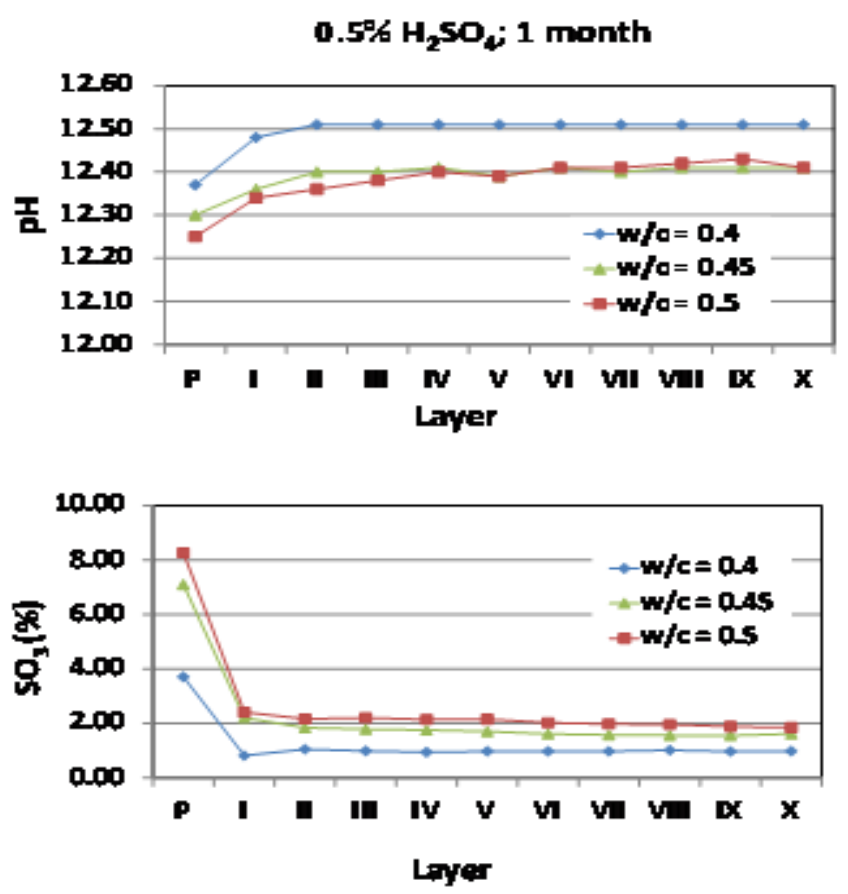

\section{RESULTS AND DISCUSSION}

After one month standing of concrete in a solution of $0.5 \%$ sulfuric acid, the $\mathrm{pH}$ reduction of aqueous leaches of layers $\mathrm{P}$ and $\mathrm{I}$ was observed for $\mathrm{w} / \mathrm{c}=0.4$ and 0.45 . Layers II $-\mathrm{X}$ showed the constant $\mathrm{pH}$ of aqueous leaches of 12.51 for w/c $=0.4$ and 12.41 for $\mathrm{w} / \mathrm{c}=0.45$. A slight decrease in $\mathrm{pH}$ of layers $\mathrm{P}-$ III was detected for sample prepared with $\mathrm{w} / \mathrm{c}=$ 0.5. This small decrease in $\mathrm{pH}$ of layers II and III, unobserved in previous samples, may be caused by larger porosity and thus easier penetration of sulfates into the higher layers of the sample. The decrease in $\mathrm{pH}$ of layers $\mathrm{P}$ is logical due to the contact of the layer directly with the acid. Layers I showed a very slight decrease in $\mathrm{pH}$ by approx. 0.03 units. It can be concluded that after 1 month contacting of concrete sample with sulfuric acid to a concentration of $0.5 \%$, no significant changes occurred in $\mathrm{pH}$ of concrete. The content of sulfate in particular layers of the samples is graphically compared in Figure 3. Increased concentration of sulfates was observed only in the layer P. In other layers content of sulfates remained almost unchanged in all samples. Sulfate ions thus do not penetrate after 1 month standing of concrete samples in $0.5 \% \mathrm{H}_{2} \mathrm{SO}_{4}$ into a greater depth than $5 \mathrm{~mm}$ regardless of the w/c.
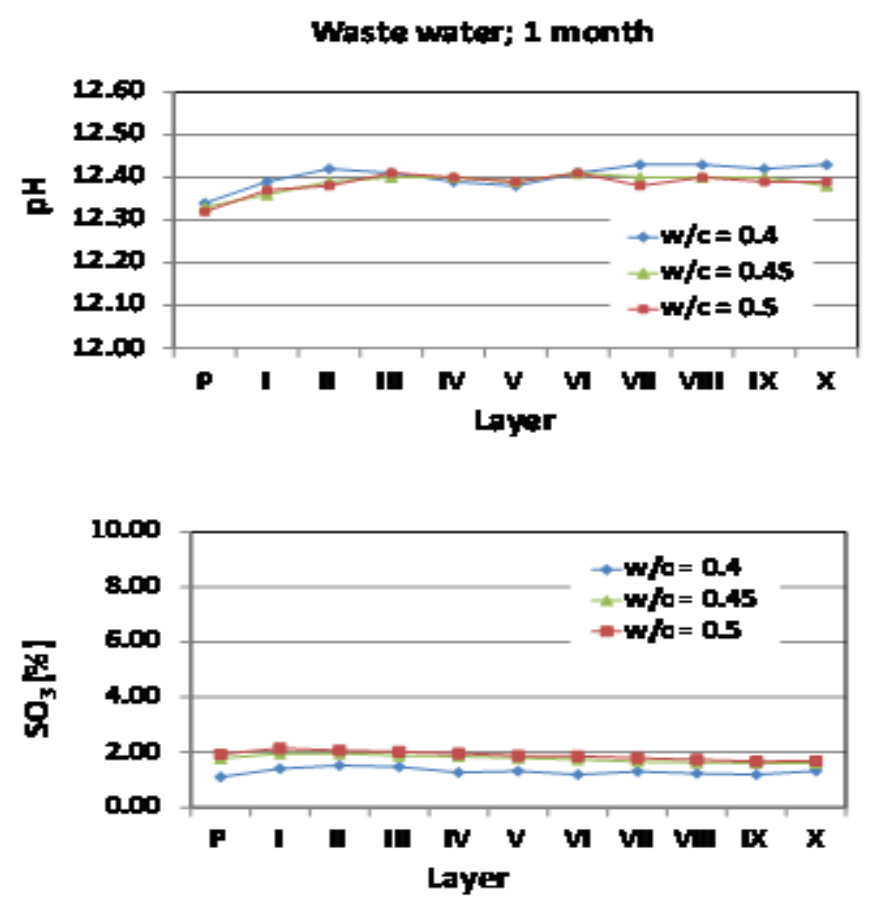

Fig. 3: Content of sulfates and $\mathrm{pH}$ of aqueous leaches of particular layers of concrete samples made with different water to cement ratio after 1 month standing in $0.5 \% \mathrm{H}_{2} \mathrm{SO}_{4}$ and waste water 
The changes at $\mathrm{pH}$ of aqueous leaches of particular layers of concrete samples standing in the waste water were lesser perceptible and sulfate content was not dramatically changed for all tested w/c. It was confirmed that the waste water itself does not cause significant corrosive effect on concrete and that microbiologically induced sulfate corrosion of concrete, which takes place above the water line in sewer systems, is much more damaged.

Figure 4 illustrates the effect of $0.5 \%$ sulfuric acid on the concrete sample with w/c $=0.45$ for 1 month. There is well recognizable white precipitate of $\mathrm{CaSO}_{4} \cdot 2 \mathrm{H}_{2} \mathrm{O}$ on the surface. Electron microscopy equipped with EDX probe showed a high content of gypsum and ettringite in the structure of layer P (see Figure 5).

Because of very similar results obtained for samples $\mathrm{w} / \mathrm{c}=$ 0.45 and 0.5 , only samples prepared with $\mathrm{w} / \mathrm{c}=0.4$ and 0.45 were selected for further tests - three-month and six-month treatment in $0.5 \%$ sulfuric acid.

It was found, that after three months standing of concrete in $0.5 \% \mathrm{H}_{2} \mathrm{SO}_{4}$ no significant changes in $\mathrm{pH}$ of aqueous leaches and content of sulfate in particular layers have been observed.

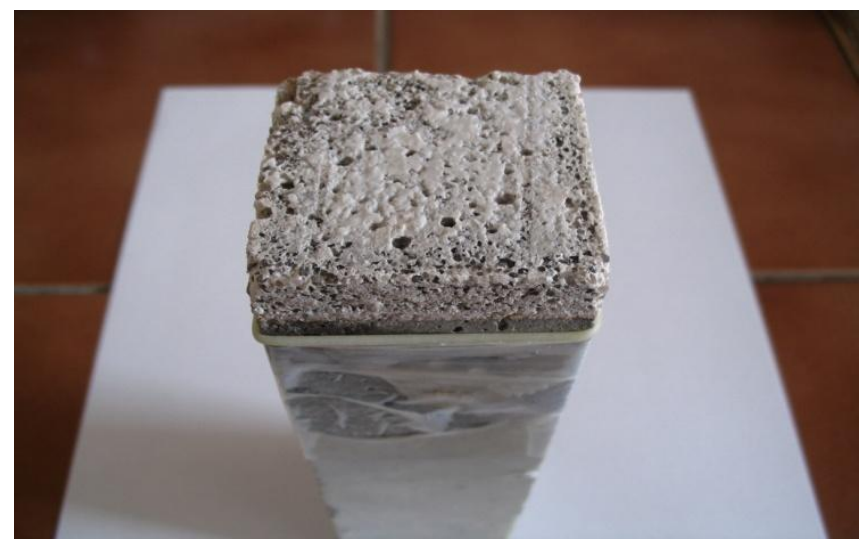

Fig. 4: The view on the immersed part of the layer $\mathrm{P}(\mathrm{w} / \mathrm{c}=$ 0.45 ) after 1 month standing in $0.5 \% \mathrm{H}_{2} \mathrm{SO}_{4}$.
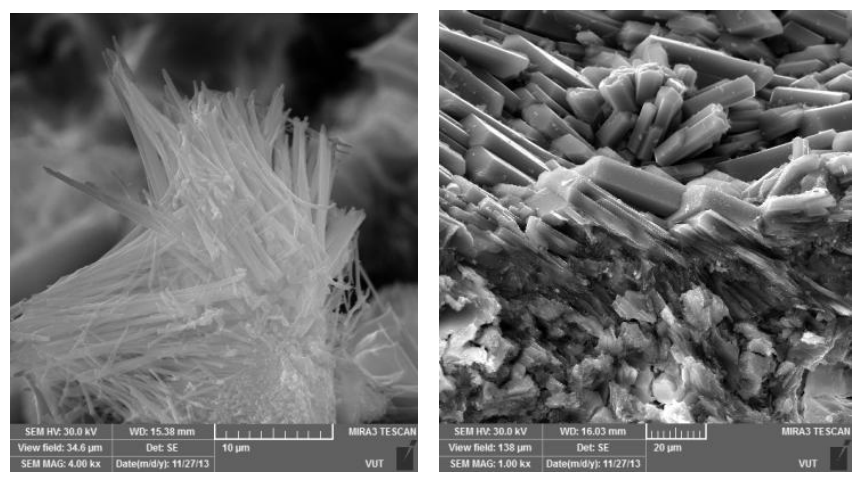

Fig. 5: SEM images of ettringite (left) and gypsum (right) identified in the structure of the layer $\mathrm{P}(\mathrm{w} / \mathrm{c}=0.45)$.

The six-month treatment of concrete samples in $0.5 \%$ sulfuric acid has already led to slight changes in $\mathrm{pH}$ of aqueous leaches (see Figure 6). The leach of layer P sample with $\mathrm{w} / \mathrm{c}=0.4$ reach a $\mathrm{pH}$ by 0.2 unit lower than after 1 month, for layer I $\mathrm{pH}$ was determined lower by 0.15 unit and the other layers showed $\mathrm{pH}$ lower by 0.1 unit. Greater differences were obtained for samples with $\mathrm{w} / \mathrm{c}=0.45$ (layer $\mathrm{P}$ - a reduction of 0.4 unit, the other layers $-\mathrm{pH}$ lower approx. by 0.2 unit). The changes of $\mathrm{pH}$ of aqueous leaches of layers $\mathrm{P}$ corresponded with increased sulfate content in these layers. The content of sulfate in layers $\mathrm{P}$ increased with increasing duration of sulfuric acid treatment. The slight increase of sulfate concentration can be observed also in layers I. In the other layers, the concentration of sulfates was not increased, although it was found lower $\mathrm{pH}$ of these layers. Sulfate ions penetrate after 6 months standing of concrete samples in $0.5 \% \mathrm{H}_{2} \mathrm{SO}_{4}$ into maximum depth of 20 $\mathrm{mm}$.

\section{$0.5 \% \mathrm{H}_{2} \mathrm{SO}_{4}$}
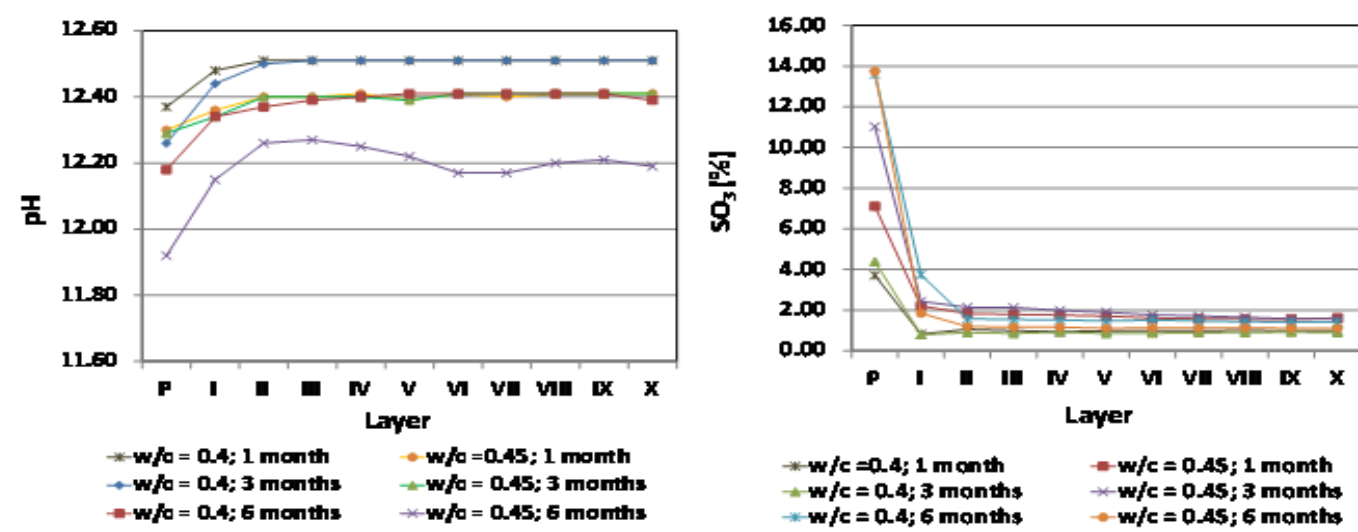

Fig. 6: Changes in $\mathrm{pH}$ of aqueous leaches of particular layers of concrete samples with w/c $=0.4$ and 0.45 and sulfate content depending on the time period of placing the samples in $0.5 \% \mathrm{H}_{2} \mathrm{SO}$ 
Despite the unchanging content of sulfates in the upper layers of the samples even after 6 months treatment in sulfuric acid a relatively significant content of ettringite was observed by electron microscope in the structure of the top layer of the $\mathrm{w} / \mathrm{c}=0.45$ sample. Comparison with the

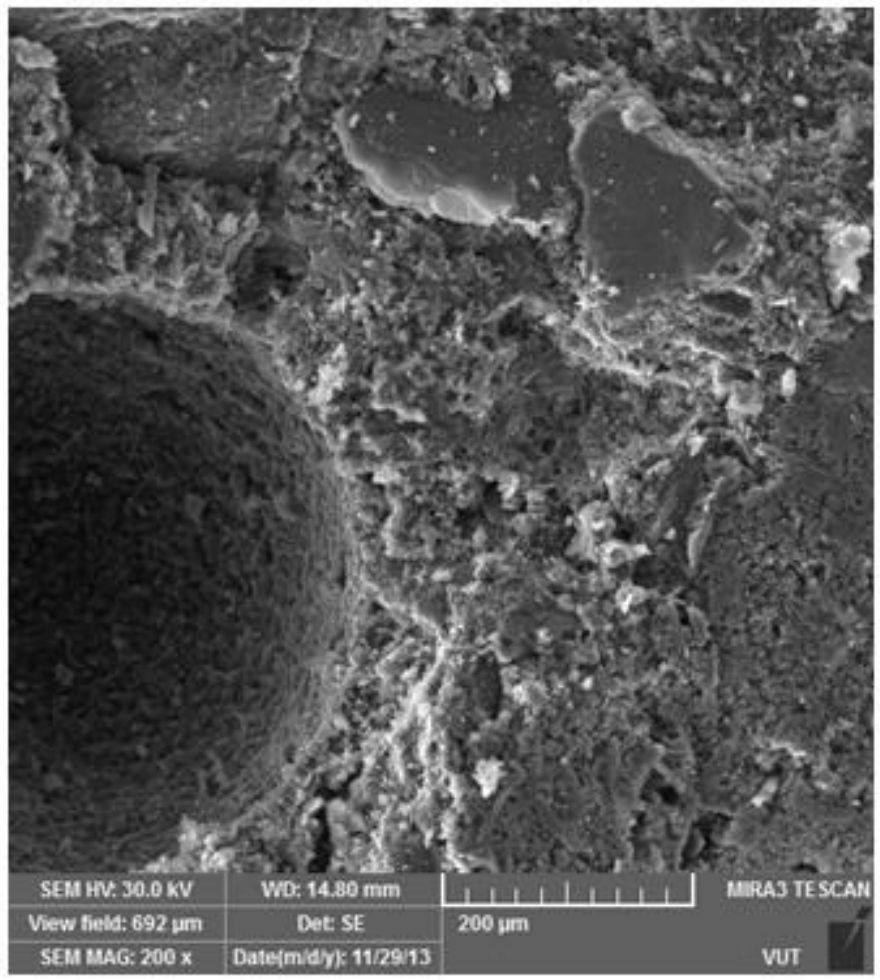

structure of the same layer before placing the sample in sulfuric acid is shown in Figure 7. Ettringite is present on the surface of the pore in typical needle crystals.

Fig. 7: SEM images of top layer of the sample w/c $=0.45$ before (left) and after (right) six months standing in $0.5 \% \mathrm{H}_{2} \mathrm{SO}_{4}$

Based on the preliminary results of a comprehensive study of sulfate corrosion the water/cement ratio for concrete samples with $\mathrm{w} / \mathrm{c}=0.45$ was selected as the best for following sulfate corrosion.

Concrete specimens exposed to $0.5 \%$ solution of sulfuric acid will be still monitored and the $\mathrm{pH}$ of aqueous leaches of the particular layers and the concentration of sulfate ions will be established after longer time period.

\section{CONCLUSIONS}

The effect of $0.5 \%$ sulfuric acid emulating microbiologically induced concrete corrosion and also effect of solution simulating sewage water on the concrete samples have been investigated by the assessment of $\mathrm{pH}$ and the content of sulfates in several layers of the specimens.

It was found that the three-month contact of the sample with $0.5 \%$ sulfuric acid does not change neither the $\mathrm{pH}$ of pore solution nor the concentration of sulfate ions in the sample. Thus, the conditions for the depassivation of reinforcement were not met.

The six-month treatment of concrete samples in $0.5 \%$ sulfuric acid solution has already led to slight changes in $\mathrm{pH}$ of pore solution. After 6 months standing of concrete

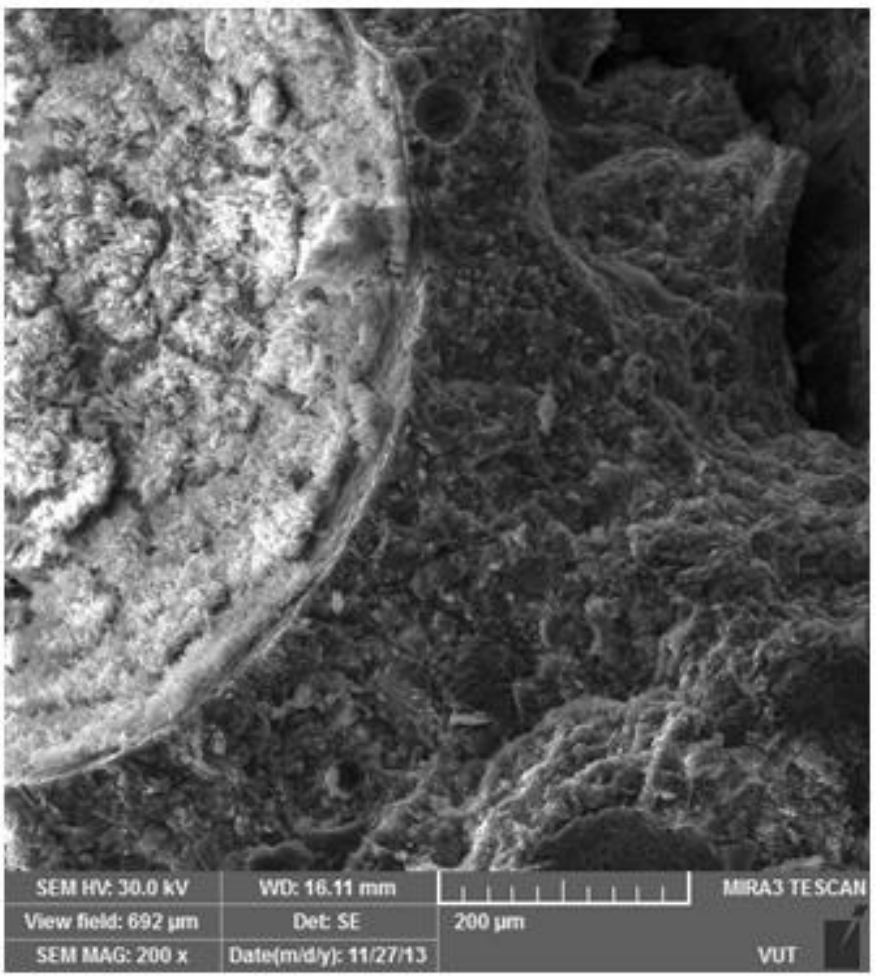

samples in $0.5 \% \mathrm{H}_{2} \mathrm{SO}_{4}$ sulfate ions has penetrated into depth of $20 \mathrm{~mm}$ maximum. The greatest changes in $\mathrm{pH}$ and the content of sulfate occurred in sample $\mathrm{w} / \mathrm{c}=0.45$ and therefore it was chosen for further study of sulfate corrosion.

\section{ACKNOWLEDGEMENTS}

This outcome has been achieved with the financial support of the Czech Science Foundation (grant no 13-22899P).

\section{REFERENCES}

[1] LORENTE, S., YSSORCHE-CUBAYNES, M.-P., AUGER, J. Sulfate transfer though concrete: Migration and diffusion results. Cem. Concr. Com. 2011, Vol. 33, p. 735-741.

[2] SUN, Ch., CHEN, J., ZHU, J., ZHANG, M., YE, J. A new diffusion model of sulfate ions in concrete. Constr. Build. Mater. 2013, Vol. 39, p. 39-45.

[3] SARKAR, S., MAHADEVAN, S., MEEUSSEN, J.C.L., SLOOT, H. van der, KOSSON, D.S. Numerical simulation of cementitious materials degradation under external sulfate attack. Cem. Concr. Com. 2010, Vol. 32, p. 241-252.

[4] NEVILLE, A. The confused world of sulfate attack on concrete. Cem. Concr. Res. 2004, Vol. 24, p. 1275-1296. ISSN 0008-8846. 
[5] YUAN, H., DANGLA, P., CHATELliER, P., CHAUSSADENT, T. Degradation modelling of concrete submitted to sulfuric acid attack. Cem. Concr. Res. 2013, Vol. 53, p. 267-277.

[6] FERNANDES, I. et al. Identification of acid attack on concrete of a sewage system. Mat. Struct. 2012, Vol. 45, No. 3, p. 337-350. ISSN 1359-5997.

[7] BELIE DE, N. et al. Experimental research and prediction of the effect of chemical and biogenic sulfuric acid on different types of commercially produced concrete sewer pipes. Cem. Concr. Res. 2004, Vol. 34, p. 2223-2236. ISSN 0008-8846.

[8] STEIN, D. Instandhaltung von Kanalisationen. $3^{\text {rd }}$ edition, Berlin: Ernst, 1999, p. 141. ISBN 3-43301315-2. (in German)

[9] SCHUEREMANS, L., GEMERT, D.V., GIESSLER, S. Chloride penetration in RCstructures in marine environment - Long term assessment of a preventive hydrophobic treatment. Constr. Build. Mater. 2007, Vol. 21, p. 1238-1249.

[10] GUTIERREZ-PADILLA, M.G.D. et al. Biogenic sulfuric acid attack on different types of commercially produced concrete sewer pipes. Cem Concr. Res. 2010, Vol. 40, No. 2, p. 293-301. ISSN 0008-8846.

[11] GIRARDI, F., MAGGIO DI, R. Resistance of concrete mixtures to cyclic sulfuric acid exposure and mixed sulfates: Effect of the type of aggregate. Cem. Concr. Res. 2011, Vol.33, p.276-285. ISSN 0008-8846.

[12] SCHMIDT, T. et al. Physical and microstructural aspects of sulfate attack on ordinary and limestone blended Portland cements. Cem. Concr. Res. 2009, Vol. 39, p. 1111-1121. ISSN 0008-8846.

[13] BELLMANN, F., ERFURT, W., LUDWIG, H.-M. Field performance of concrete exposed to sulfate and low $\mathrm{pH}$ conditions from natural and industrial sources. Cem. Concr. Res. 2012, Vol. 34, p.86-93. ISSN 0008-8846.

[14] BROWN, P.W. An evaluation of the sulfate resistance of cements in a controlled environment. Cem. Concr. Res. 1981, Vol. 11, No. 5-6, p.719727. ISSN 0008-8846.

[15] OUYANG, CH., NANNI, A., CHANG, W.F. Internal and external sources of sulfate ions in Portland cement mortar: two types of chemical attack. Cem. Concr. Res. 1988, Vol. 18, No. 5, p. 699-709. ISSN 0008-8846.

[16] SANTHANAM, M., COHEN. M., OLEK, J. Differentiating seawater and groundwater sulfate attack in Portland cement mortars. Cem. Concr. Res. 2006, Vol. 36, p. 2132-2137. ISSN 00088846.

[17] Czech Standards Institut. Cement - Part 1: Composition, specifications and conformity criteria for common cements. Czech Standards Institut; 2012 [CSN EN 197-1 ed. 2] (in Czech)

[18] Czech Standards Institut. Quartz sands. Fundamental technical requirements. Czech Standards Institut; 1994 [CSN 72 1200] (in Czech)

[19] BELIE. De N, et al. Experimental research and prediction of the effect of chemical and biogenic sulfuric acid on different types of commercially produced concrete sewer pipes. Cem. Concr. Res. 2004, Vol. 34, p. 2223-2236. ISSN 0008-8846.

[20] PELL. M, LJUNGGREN. H. Composition of the bacterial population in sand-filter columns receiving artificial wastewater, evaluated by soft independent modelling of glass analogy (SIMCA). Wat. Res. 1996, Vol. 30, p. 2479-2487. ISSN 0043-1354.

\section{BIOGRAPHIES}

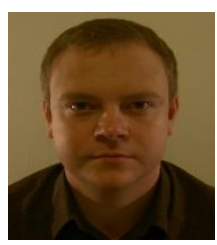

Martin Vyšvařil received the $\mathrm{PhD}$ degree in Inorganic Chemistry from MU, Czech Republic. He is currently working as an assistant professor at FCE BUT. His research interests comprehend chemistry of building materials - investigation in modification and utilization of new building materials and degradation processes in concrete structures. $\mathrm{He}$ is a specialist for RTG fluorescence analysis.

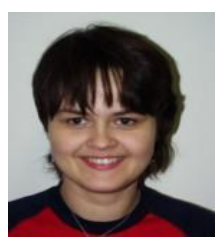

and modelling structures.

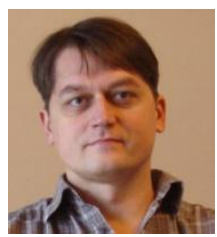

Markéta Rovnaníková received the $\mathrm{PhD}$ degree in Chemistry, Technology, and Properties of Materials from FCH BUT, Czech Republic. She is currently working as a research fellow at FCE BUT. Her research interests concern the investigation of degradation processes in concrete

Patrik Bayer received his $\mathrm{PhD}$ degree from the FCE BUT, Czech Republic. He is currently working as an assistant professor at FCE BUT. He is a specialist for SEM and porosity measurements. 